\title{
Intracranial reticulum cell sarcoma associated with immunoglobulin A deficiency
}

\author{
M. C. GREGORY ${ }^{1}$ AND J. T. HUGHES \\ From the Departments of Neurology and Neuropathology, United Oxford Hospitals, Oxford
}

SUMMARY A case is reported of a 46 year old woman who died after a five month illness characterized by focal neurological signs, evidence of meningeal irritation, and the finding of 'blast' cells in the CSF. Immunoglobulin A was consistently absent from her serum and secretions. Necropsy showed extensive infiltration by a reticulum-cell sarcoma of the subarachnoid space, with tumour nodules on several cranial nerves and tumour infiltration of the tuber cinereum. The significance of the association between immunoglobulin A deficiency and neoplasia is discussed.

Although increasing numbers of intracranial reticulum cell sarcomas and microgliomas have been reported (Russell, Marshall, and Smith, 1948; Burstein, Kernohan, and Uihlein, 1963; Adams and Jackson, 1966; Gunderson, Henry, and Malamud, 1971; Schaumberg, Plank, and Adams, 1972), primary mesenchymal tumours of the central nervous system account for only 0.25 to $0.7 \%$ of all brain tumours (Sorger, 1963). Burstein et al. (1963) found 31 of 242 primary brain sarcomas were reticulum cell sarcomas or microgliomas. The observations of Hutchinson, Leonard, Maudsley, and Yates (1958), Williams, Diamond, Craver, and Parsons (1959), and of Currie and Henson (1971) concern a total of 7,781 patients with reticuloses and of these none involved the central nervous system primarily.

By contrast, this type of tumour is surprisingly common in transplantation recipients treated with immunosuppressive drugs. Schneck and Penn (1971) reported 24 mesenchymal neoplasms which had occurred in 5,000 renal and 170 cardiac transplant recipients. Of these eight involved the brain alone and three more the brain together with extracerebral sites. Nine of these tumours were reticulum cell sarcomas and two were unclassified lymphomas.

The following case of reticulum cell sarcoma is reported because there was a total absence of

1 Present address: Department of the Regius Professor of Medicine, Radcliffe Infirmary, Oxford. immunoglobulin A, an association which has not been described previously.

\section{CASE REPORT}

CLINICAL HISTORY W.J. was a 46 year old white housewife. She was admitted to hospital on 13 January 1971, a few hours after the sudden onset of coma and right hemiplegia. Her past history included cholecystectomy and blood transfusion, excision of a tuberculous cervical gland, and two uneventful pregnancies. For one month before her admission she had felt lethargic, dizzy, and anorexic and had noted occasional epistaxes and headaches.

On admission she was comatose with a right hemiplegia, with positive Kernig's sign and neck stiffness. Lumbar puncture yielded sterile fluid containing 2,000 leucocytes/c. mm, $95 \%$ of which were interpreted as lymphocytes and the remainder as polymorphonuclear leucocytes. Two days after the onset of coma and hemiplegia she rapidly made an almost complete recovery, but over the ensuing month she developed severe visual loss and was treated with corticotrophin (ACTH). A month after the onset she was transferred to the Churchill Hospital, Oxford, at which stage her vision was reduced to perception of light in the right eye and Jaeger 20 in the left. She also had a right lower motor neurone facial palsy, positive Kernig's sign, neck stiffness, and diffuse limb weakness with hyporeflexia in the left lower limb. Despite prominent sensory symptoms, there were no objective sensory signs.

INVESTIGATIONS Cerebrospinal fluid (CSF) (18 
February 1971.) Pressure exceeded $300 \mathrm{~mm}$ of water. The CSF contained: protein $520 \mathrm{mg} / 100 \mathrm{ml}$., glucose $44 \mathrm{mg} / 100 \mathrm{ml}$., 9,600 leucocytes/c. mm; cytological examination (Dr. A. I. Spriggs) showed these to be nearly all lymphoblasts with large nuclei, some in mitosis, prominent nucleoli, and scanty cytoplasm (Fig. 1).

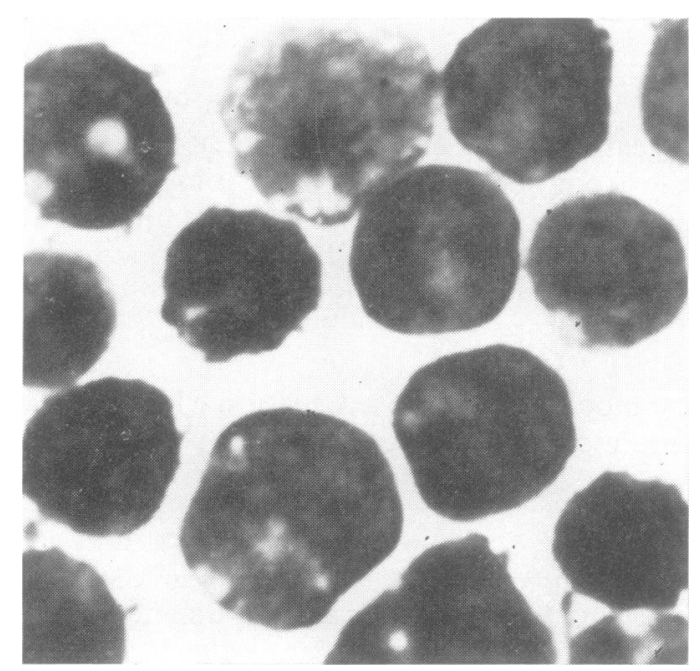

FIG. 1. Stained film of CSF obtained before intrathecal administration of methotrexate. The cells are 'blast' forms with scanty cytoplasm and large nuclei with nucleoli May-Grünwald-Giemsa, $\times 1,800$. (Picture supplied by Dr. A. I. Spriggs.)

Haematology Peripheral blood film, haemoglobin, total and differential white cell count, and platelet count were repeatedly normal. No abnormal cells were found in buffy coat preparations, but from 28 April 1971 until 26 May 1971 leucocytes were consistently observed to clump during preparation of routine peripheral blood films. Bone marrow examinations (18 February 1971, 15 March 1971, 14 April 1971, 22 June 1971) were normal. Examinations for LE cells and antinuclear factor were negative. The serum $B_{12}$ level was $350 \mathrm{pg} / \mathrm{ml}$., serum folate $2.6 \mathrm{ng} / \mathrm{ml}$., serum iron $75 \mu \mathrm{g} / 100 \mathrm{ml}$., total iron binding capacity $435 \mu \mathrm{g} / \mathrm{ml}$. Erythrocyte sedimentation rate (Westergren) varied between $8 \mathrm{~mm} /$ hour and $139 \mathrm{~mm} /$ hour.

Biochemistry Plasma urea, electrolytes, calcium, phosphorus, total protein and albumin, fasting glucose, bilirubin, and uric acid were repeatedly $\underset{\mathbb{Q}}{Z}$

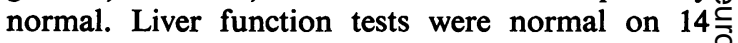
January 1971 , but by 18 February were moderately abnormal (aspartate aminotransferase 270 SF units, LDH $180 \mathrm{mi}$.u./ml., alkaline phosphatase $22.0 \mathrm{KA} 0$ units. Protein electrophoresis showed increased $\alpha_{2}-\stackrel{\infty}{<}$ and $\gamma$-globulins). The high aspartate aminotrans- $\stackrel{5}{=}$. ferase and the abnormal electrophoretic strip returned $\stackrel{0}{\vec{*}}$ to normal levels over the next fortnight, whereas the alkaline phosphatase remained mildly elevated $(9 \cdot 9-\overrightarrow{\vec{F}}$ $22.8 \mathrm{KA}$ units, $5^{\prime}$-nucleotidase $11.4 \mathrm{U}$ ) throughout her illness. Bence Jones protein was absent from the urine and repeated urine electrophoresis was $\frac{\bar{c}}{\bar{\omega}}$ negative. Both the five day faecal fat excretion $(2.0 \mathrm{~g} / \overrightarrow{\mathrm{D}}$ 24 hours) and the xylose tolerance test ( $7 \mathrm{~g}$ excretion $\bigcirc$ in five hours after $25 \mathrm{~g}$ load) were normal.

Serology WR and Kahn (18 February 1971) were weakly positive in blood, but not in CSF. RPCFT $\vec{\omega}$ was doubtful and VDRL and FTA (Abs) were negative. This was assumed to be a biological false positive WR but was treated with penicillin nevertheless (at the same time as methotrexate was given), and the WR and Kahn tests rapidly became negative Coombs test, rheumatoid factor, hepatitis associatea antigen, and glandular fever screening tests were 을 negative.

Virology No virus was isolated from CSF or blood No cytomegalovirus was isolated from the urine Serum antibody titres were as shown in the Table.

TABLE

ANTIBODY TITRES

\begin{tabular}{|c|c|c|c|c|c|}
\hline & $\begin{array}{c}18 \mathrm{Feb} . \\
1971\end{array}$ & $\begin{array}{c}3 \text { Mar. } \\
1971\end{array}$ & $\begin{array}{c}12 \text { Mar. } \\
1971\end{array}$ & $\begin{array}{c}28 \text { Apr. } \\
1971\end{array}$ & $\begin{array}{l}21 \text { June } \\
1971\end{array}$ \\
\hline $\begin{array}{l}\text { Mumps V } \\
\text { Mumps S } \\
\text { Measles } \\
\text { Measles (CSF) } \\
\text { Herpes simplex } \\
\text { Varicella/zoster } \\
\text { Cytomegalovirus } \\
\text { Cytomegalovirus (CSF) } \\
\text { Leptospira }\end{array}$ & $\begin{array}{r}32 \\
16 \\
128 \\
8 \\
8 \\
8 \\
32\end{array}$ & $\begin{array}{r}128 \\
2\end{array}$ & $\begin{array}{r}256 \\
2\end{array}$ & $\begin{array}{r}32 \\
16 \\
64 \\
\\
4 \\
16\end{array}$ & $\begin{array}{r}256 \\
2 \\
1,024\end{array}$ \\
\hline
\end{tabular}

Immunology IgA was indetectable in serum on five occasions (18 February-22 June 1971) with normal serum levels of IgG and IgM. No IgA was detectable in saliva or CSF. IgA levels in serum and saliva of the patient's husband, brother, sister, and both daughters were normal. (IgA assays were performed by Dr. J. A. Morton.) Mantoux reaction at 1/1,000 was negative (despite previous cervical adenitis). 
Cytotoxic B-cell function was markedly reduced and lymphocyte response to phytohaemagglutinin was mildly impaired as assessed by the methods of Campbell, MacLennan, Snaith, and Barnett (1972) (Dr. D. P. Jewell). Blood group was O Rh-positive. Anti-Kell antibodies were at a titre of $1 / 128$ by Coombs test (previous transfusion).

Radiology Repeated radiographs of the chest, frontal and lateral mediastinal tomograms, plain abdominal films, skeletal survey, excretion urogram, barium meal and follow-through, and abdominal lymphangiogram were normal. Radiographs of the skull and repeated brain scans and a left carotid angiogram were normal.

Electrophysiology The electrocardiogram was normal apart from mild repolarization changes. Electromyograms showed evidence compatible with lesions of both sensory and motor roots. Serial electroencephalograms demonstrated mild, but progressive, non-specific bilateral abnormalities.

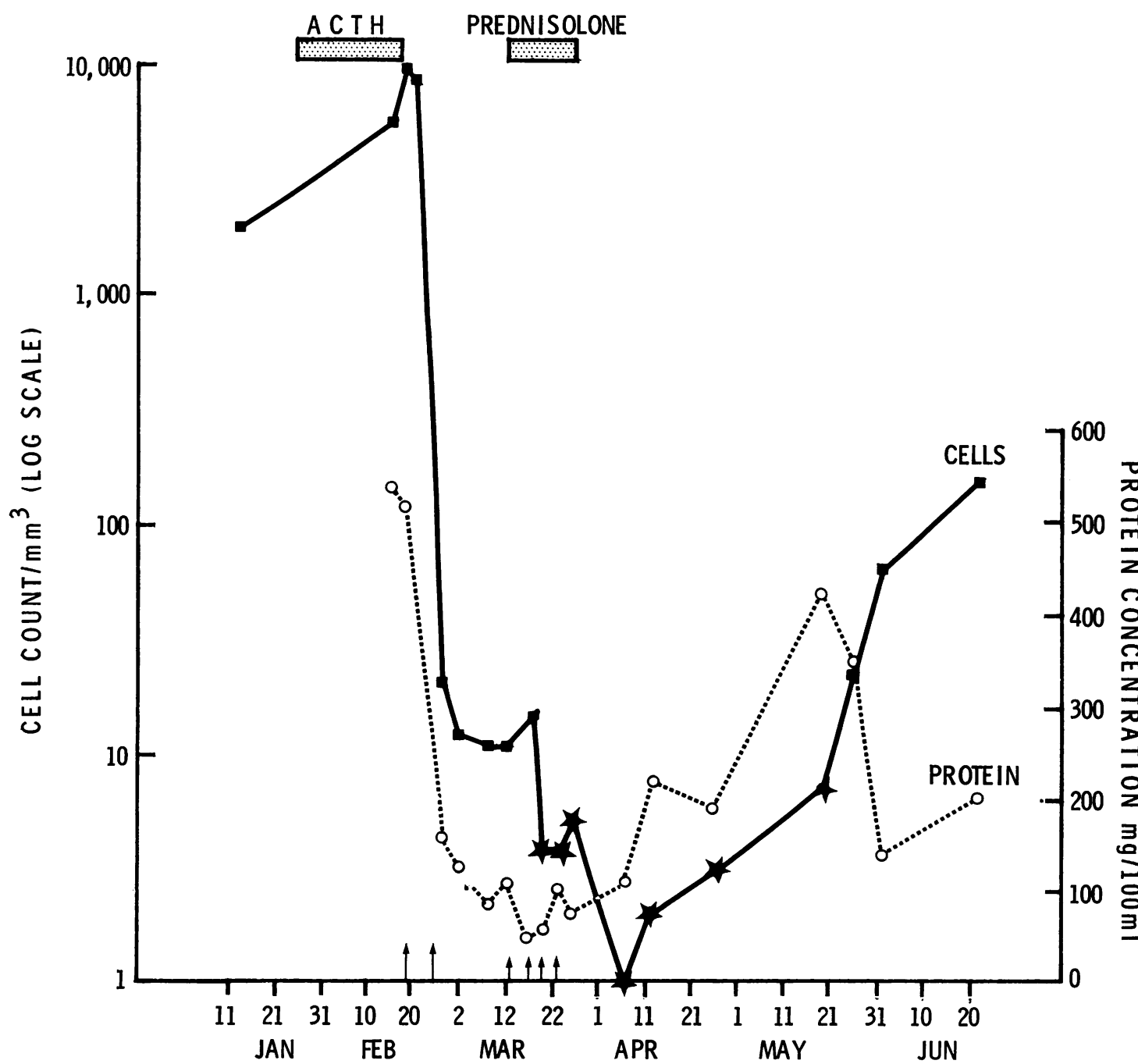

FIG. 2. CSF cell counts and protein levels. Open circles represent the concentration of CSF protein. Black squares represent the CSF white cell count (blast cells present). Stars represent the CSF white cell count during the period when no blast cells were present. Each vertical arrow indicates an intrathecal injection of methotrexate. 
Liver biopsy The liver architecture was normal. Some portal tracts were infiltrated with round cells and an occasional focus of similar cells was seen in the liver parenchyma.

Jejunal biopsy A jejunal biopsy showed normal morphology apart from the absence of a germinal centre from a lymphoid follicle included in the biopsy. Plasma cells were shown by immunofluorescence (Dr. J. M. Skinner) to be producing immunoglobulins $G$ and $M$ but not immunoglobulin A.

TREATMENT AND PROGRESS A clinical diagnosis of a malignant lymphoblastic 'meningitis' was made, and

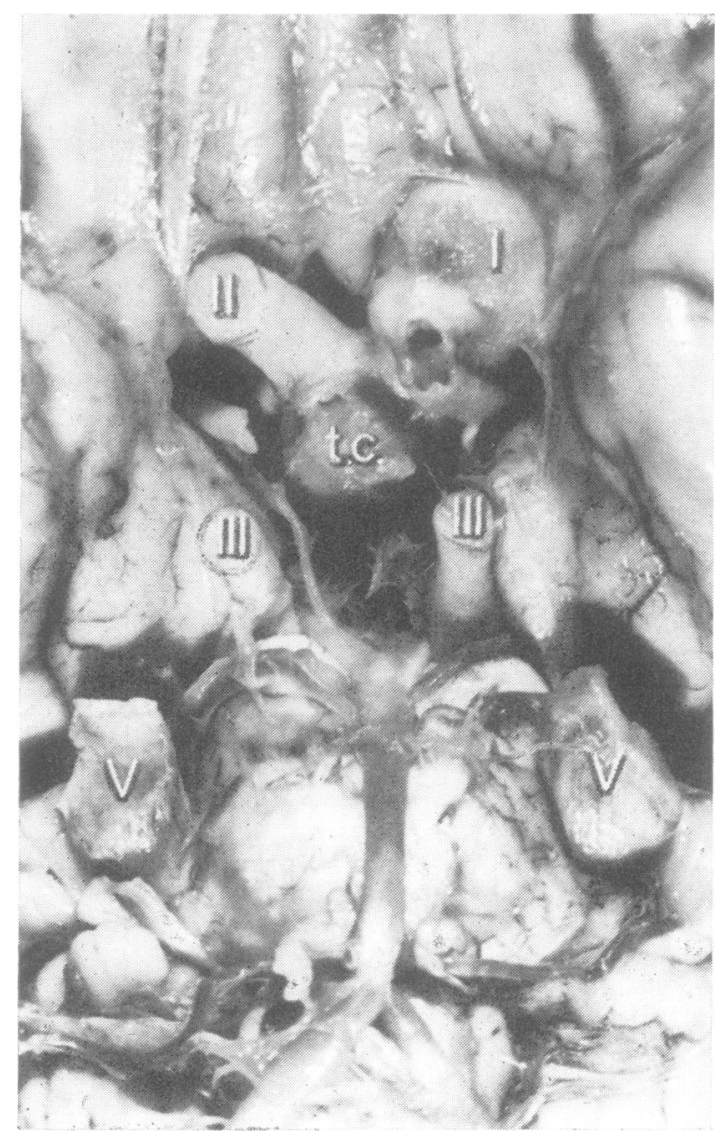

FIG 3. Base of formalin-fixed brain of patient. Tumours are present in relation to the left olfactory nerve (I), right optic nerve (II), both oculomotor nerves (III), and both trigeminal nerves (V). The tuber cinereum (t.c.) is also expanded by tumour.
$17.5 \mathrm{mg}$ methotrexate was injected intrathecally on 19 February 1971 : a further dose of $17.5 \mathrm{mg}$ and four subsequent $10 \mathrm{mg}$ doses were given. Clinical improvement was dramatic. Within three days her vision began to improve and visual acuity eventually returned to left Jaeger 2, right Jaeger 1 . The facial weakness resolved almost completely, and she was then able to walk. The changes in the protein and cells of the CSF are shown in Fig. 2. The immature 'blast' cells disappeared from the CSF on 19 March and were seen again on 26 May. Clinical remission was maintained until 6 April; after that date she developed a severe but fluctuating, asymmetrical polyneuropathy. Other features of this last phase of the illness included visual hallucinations, transient bilateral cortical blindness, bilateral optic atrophy, bilateral internal and external ophthalmoplegia, and root pains. Hyponatraemia-plasma sodium ranged from 120 to $130 \mathrm{mN}$ and plasma chloride from 84 to $95 \mathrm{mN}$ for a period of six weeks - was thought, on the basis of plasma and urine osmolalities and ionic contents and of the greater response to water deprivation than to salt administration, to be due to inappropriate secretion of antidiuretic hormone (ADH). Finally, she developed widespread myoclonie jerks and died in coma on 26 June 1971.

NECROPSY The heart was normal, but the pericardia cavity was obliterated by an adhesive pericarditis Both lungs were affected by acute bronchopneuo monia. The liver weighed $1,740 \mathrm{~g}$, and was pale wit discoloured areas having a greyish pattern. Sections $\overrightarrow{0}$ showed a cellular infiltration in the portal tracts. The spleen weighed $186 \mathrm{~g}$ and was moderately enlarged, soft, and grey in colour. Sections showed a diffuse cellular infiltration of the pulp, suspicious of a malignant proliferation, and a definite microscopical tumour infiltration around the hilum. The lymph nodes in all regions were soft and moderately enlarged. Histology showed that the architecture was relatively well preserved, but that the follicles and sinuses appeared to be abnormally cellular, probably due to a malignant infiltration. The kidneys weighed $122 \mathrm{~g}(\mathrm{~L})$ and $110 \mathrm{~g}(\mathrm{R})$. Histological examination showed minor tumour infiltration around the renal pelves. The sphenoidal sinus and the nasopharynx were free of tumour both macroscopically and histologically.

The brain weighed $1,170 \mathrm{~g}$. Several tumours were seen at the base of the brain and most of these were related to cranial nerves (Fig. 3). The largest tumour measured $1.5 \times 1.0 \times 1.0 \mathrm{~cm}$ : it was situated in the posterior part of the olfactory groove and was attached to the left olfactory nerve. The right optic nerve was expanded to $1 \mathrm{~cm}$ in diameter by diffuse tumour infiltration. Both oculomotor nerves were 


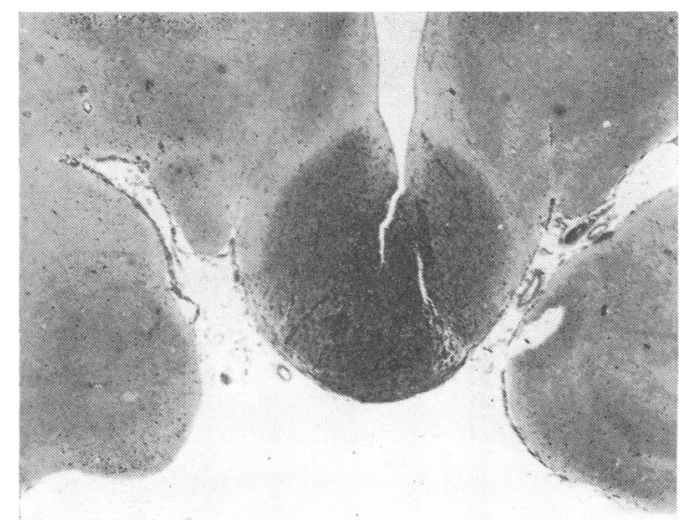

FIG. 4. Photomicrograph of coronal section of brain at the level of the third ventricle. There is extensive tumour infiltration of the tuber cinereum and tumour spread (seen as a thin dark line) in the subarachnoid space. Haematoxylin and eosin, $\times 2$.

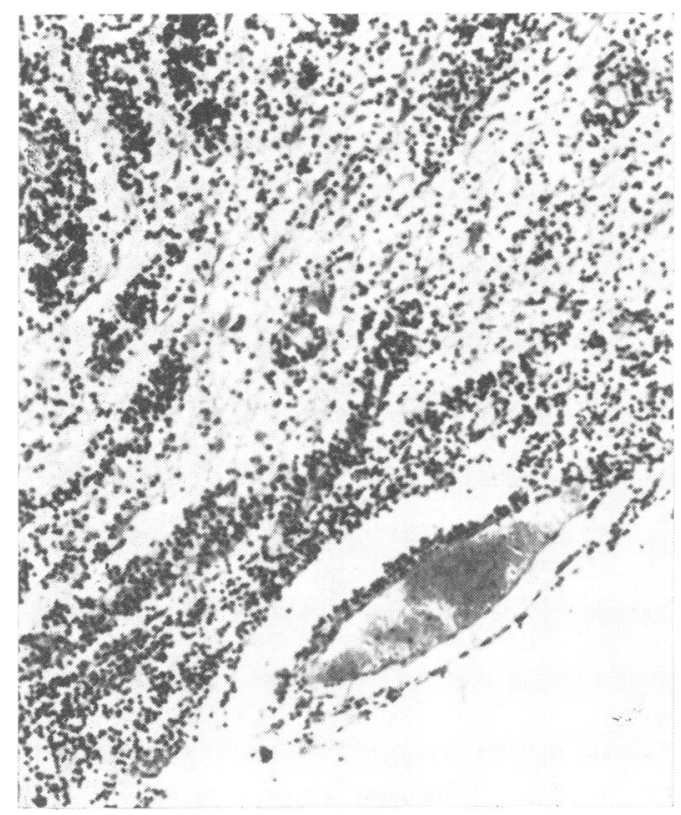

FIG. 5. Photomicrograph at higher magnification than in Fig. 3 and showing the detail of the edge of the tuber cinereum. The tumour is infiltrating diffusely and also spreading perivascularly. There is continuity of tumour between the brain and the subarachnoid space. Haematoxylin and eosin, $\times 110$.

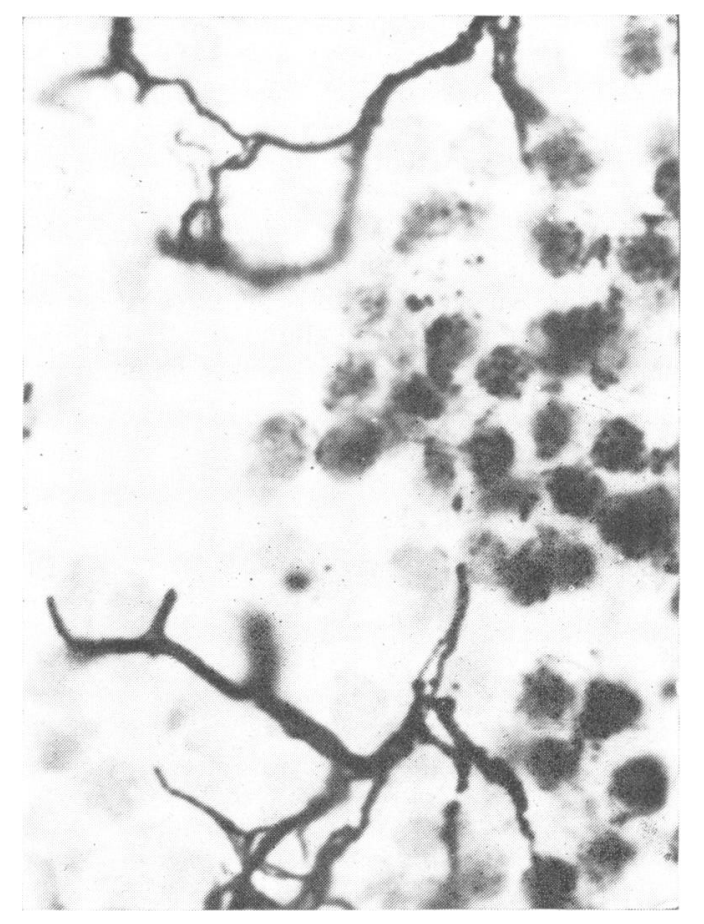

FIG. 6. Photomicrograph of section from tuber cinereum stained for reticulin fibres. There is a network of reticulin in relation to the tumour cells. Gordon and Sweet's method for reticulin, $\times 600$.

involved in small round tumours. Both trigeminal nerves were expanded by moderate-sized tumours. On slicing the formalin-fixed brain coronally, the tuber cinereum was seen to be expanded by tumour over an area measuring $1.2 \mathrm{~cm}$. No other tumours were present within the brain. Sections of the brain showed diffuse tumour infiltration of the tuber cinereum (Fig. 4), tumour infiltration of the subarachnoid space at the base of the brain (Figs 4 and 5 ), and the tumour nodules on the cranial nerves described above. The spinal cord, which appeared normal macroscopically, showed in histological sections extensive tumour infiltration of the subarachnoid space and of the spinal nerve roots. The peripheral nerve trunks in the limbs showed profound Wallerian degeneration and there was denervation atrophy affecting the limb muscles.

The histological structure of the tumour (Figs 5, 6 , and 7), whether seen in relation to the brain and spinal cord or in the other viscera, was similar. The tumour cells were of two types (Fig. 7) in varying proportions. One type was a small round cell with 
very scanty cytoplasm and a densely staining nucleus often in mitosis. In the areas where these cells predominated the appearances were those of a lymphosarcoma. The other type of cell was generally larger but more varied in size and shape, with a large, rather palely staining vesicular nucleus and a moderate amount of cytoplasm. Mitotic figures were again common. Special staining techniques for reticulin (Fig. 6) showed small strands of reticulin between individual tumour cells and abundant reticulin in the stroma separating the larger groups of tumour cells.

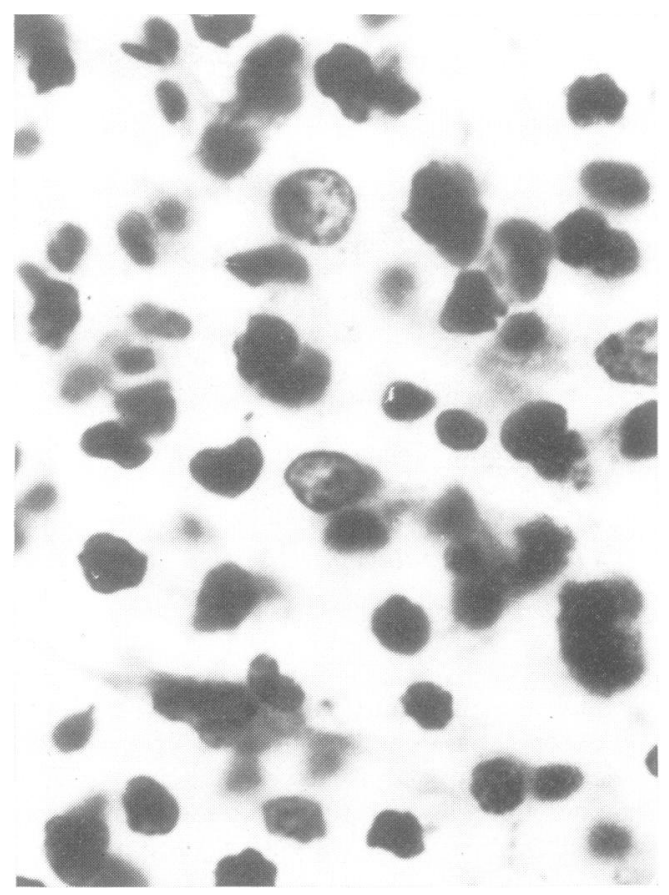

FIG. 7. Photomicrograph of a section from tuber cinereum stained by Hortega's silver technique for microglia. The nuclei and the scanty cytoplasm of the tumour cells can be seen but there are no glial processes. Control sections showed good impregnation of microglia. $\times 600$.

The Weil-Davenport and the Hortega (Fig. 7) silver techniques for microglia showed no specific staining of the tumour cells.

A search by electron microscopy in the nuclei and cytoplasm of the tumour cells for virus particles was unsuccessful. The two populations of tumour cells were identified. The smaller tumour cell type lacked specific features. The cytoplasm of the larger tumour cell type had an extensive endoplasmic reticulum.

\section{DISCUSSION}

The principal interest of this case lies in the unusual presentation of a rare tumour and the relevance of the finding of immunoglobulin A deficiency.

For a lymphoma to present with cerebral involvement and to be diagnosed by the finding of blast cells in the CSF at a time when blood and bone marrow studies are normal is very unusual. In acute lymphoblastic leukaemia, lymphoblasts in the CSF may accompany the other generalized manifestations of the disease but do not precede them (Spriggs and Boddington, 1959). The case described here was remarkable in that, at necropsy, extensive tumour infiltration was present around the brain and spinal cord, but only slight tumour infiltration could be found ip the lymph nodes, spleen, liver, and kidneys. Foo two reasons, this distribution of tumour cannos easily be explained by the therapy employed. The earliest symptoms and the clinical course of the disease indicated that the localization through out was similar to that demonstrated at necrops Secondly, intrathecal methotrexate, the ons effective therapy used, would be expected to have $\omega$ a feeble effect outside the central nervous system. Other observers (Russell et al., 1948; Crosato and Zappoli, 1958) have described cases in which a substantial tumour infiltration of the brain was accompanied by relatively minor tumour infiltration or a lymphoid hyperplasia of other organs. The present tumour has been classified as a reticulum-cell sarcoma because of the microscopical appearance of the tumour cells and the demonstration of reticulin production by the tumour. The diagnosis of microglioma was rejected because specific silver techniques for microglia were negative and the maximal distribution of the tumour in the subarachnoid space at the base of the brain suggested that the tumour infiltration of the tuber cinereum (the only site of tumour in the brain) was a secondary invasion. The distinction between a tumour of microglia and a tumour of the primitive reticulum cell is controversial (Russell et al., 1948; Burstein et al., 1963; Adams and Jackson, 1966; Schaum- 
berg et al., 1972) and these tumours might be classified differently by different authorities. The main disagreement is between those who would embrace all such tumours in one category and those who insist on separating tumours of microglial origin from those arising in reticulum cells.

The occurrence in this case of widespread peripheral neuropathy was probably due to direct involvement of nerve roots, and this was demonstrated at necropsy: polyneuropathy as a non-metastatic manifestation of reticulum cell sarcoma is very rare (Schaumberg et al., 1972).

Agonal ADH hypersecretion in a case of widespread reticulum-cell sarcoma was described by Miller, Ashkar, and Rudzinski (1971), and attributed by them to the secretion of an $\mathrm{ADH}-$ like polypeptide by the tumour. In our case, this complication could be explained by the involvement of the tuber cinereum by the tumour. Bauman, Lopez-Amor, and Dingman (1972), using bioassay methods, found much higher serum levels of ADH in a patient with bronchial carcinoma and metastases near the hypothalamus than in other patients who did not have intracranial metastases from similar ADH-secreting carcinomas.

Some idea of the frequency of an indetectably low level of serum IgA can be obtained from the following surveys. Bachmann (1965) found 10 examples in an examination of 6,995 sera from healthy individuals, and Cassidy, Burt, Petty, and Sullivan (1969) in a similar study found one example in 3,024 sera. In hospital patients Hobbs (1968) found an incidence of seven in 11,000. These are examples of selective immunoglobulin A deficiency in which serum levels of IgG and $\operatorname{IgM}$ are normal. When $\operatorname{IgA}$ is absent from the serum it is usually also absent from secretions, and antibodies against $\operatorname{IgA}$ are commonly present (Tomasi, 1968; Fudenberg, Good, Goodman, Hitzig, Kunkel, Roitt, Rosen, Rowe, Seligman, and Soothill, 1971). Cellular immunity is not thought to be affected (Fudenberg et al., 1971).

The association of IgA deficiency with tumours of this kind has not been reported previously but it may be relevant that Gunderson et al. (1971) described one case of microglioma with a high serum level of IgA. Further cases are required to resolve the relationship between $\operatorname{IgA}$ status and neoplasia. Investigation of this association may elucidate the high incidence of reticulum cell sarcomas in transplant recipients. Transmission of malignant cells with the graft or a direct mutagenic action of the immunosuppressive drugs could not be operative factors in the case reported here. The concurrence of agammaglobulinaemia A and intracranial reticulum cell sarcoma admits of several explanations. It may represent the chance coincidence of two rare conditions, or the immunodeficiency may have caused the malignancy or vice versa. One way in which the immunodeficiency might be causative would be by affecting the surveillance mechanism through which the body's immune defences eliminate potentially malignant clones (Burnet, 1970). Such a mechanism, however, is more likely to be operated by cytotoxic T-cells than by a single immunoglobulin class. A second way was suggested by Hobbs (1968). If the defect of humoral immunity results in compensatory overactivity of lymphoid tissue, it might be that this exuberant proliferation would eventually progress to frank neoplasia. A third way would be if the defect permitted an oncogenic virus to enter or spread in the body. IgA is the principal immunoglobulin component of nasal secretions and its absence from this site may have allowed the entry of a virus via the cribriform plate. This route of entry could account for the distribution of tumours clustered around the base of the brain.

We have stated three mechanisms by which this tumour may have arisen. In any of these mechanisms it is possible that the concurrence of imperfections of cellular immunity (negative Mantoux reaction, depressed response to phytohaemagglutinin and reduced lymphocyte cytotoxicity) with the humoral defect may have been relevant.

Alternatively, we must consider the possibility that the tumour caused the immune deficits. Lymphoid neoplasia is known to cause cellular and humoral immune paresis, but, as far as we know, has never been responsible for a constant absence of a single immunoglobulin class (IgA) with the preservation of two other classes (IgG and IgM). The minor defects in cellular immunity may well have been consequences of the tumour.

We are indebted to Professor W. B. Matthews for permission to publish this case and to Dr. G. A. B. 
Davis-Jones for the use of his clinical records. Sir Richard Doll, FRS and Dr. A. H. T. Robb-Smith kindly read and criticized the paper.

\section{REFERENCES}

Adams, J. H., and Jackson, J. M. (1966). Intracerebral tumours of reticular tissue : the problem of microgliomatosis and reticulo-endothelial sarcomas of the brain. Journal of Pathology and Bacteriology, 91, 369-381.

Bachmann, R. (1965). Studies on the serum $\gamma$ A-globulin level. 3. The frequency of a- $\gamma \mathrm{A}-$ globulinemia. Scandinavian Journal of Clinical and Laboratory Investigation, 17, 316320

Bauman, G., Lopez-Amor, E., and Dingman, J. F. (1972). Plasma arginine vasopressin in the syndrome of inappropriate antidiuretic hormone secretion. American Journal of Medicine, 52, 19-24.

Burnet, F. M. (1970). The concept of immunological surveillance. Progress in Experimental Tumour Research, 13, 1-27.

Burstein, S. D., Kernohan, J. W., and Uihlein, A. (1963). Neoplasms of the reticuloendothelial system of the brain. Cancer, 16, 289-305.

Campbell, A. C., MacLennan, I. C. M., Snaith, M. L., and Barnett, I. G. (1972). Selective deficiency of cytotoxic B lymphocytes in man. Clinical Experimental Immunology, 12, 1-8.

Cassidy, J. T., Burt, A., Petty, R., and Sullivan, D. (1969). Selective IgA deficiency in connective tissue diseases. New England Journal of Medicine, 280, 275.

Crosato, F., and Zappoli, R. (1958). I retotelsarcomi a primitivo sviluppo endocranico. Rivistadi Patologia Nervosa e Mentale, 79, 149-188.

Currie, S., and Henson, R. A. (1971). Neurological syndromes in the reticuloses. Brain, 94, 307-320.
Fudenberg, H., Good, R. A., Goodman, H. C., Hitzig, W., Kunkel, H. G., Roitt, I. M., Rosen, F. S., Rowe, D. S., Seligmann, M., and Soothill, J. R. (1971). Primary Immunodeficiencies: report of a World Health Organization Committee. Pediatrics, 47, 927-946.

Gunderson, C. H., Henry, J., and Malamud, N. (1971). Plasma globulin determinations in patients with microglioma. Report of five cases. Journal of Neurosurgery, 35, 406-415.

Hobbs, J. R. (1968). Immune imbalance in dysgammaglobulinaemia type IV. Lancet, 1, 110-114.

Hutchinson, E. C., Leonard, B. J., Maudsley, C., and Yates, P. O. (1958). Neurological complications of the reticuloses. Brain, 81, 75-92.

Miller, R., Ashkar, F. S., and Rudzinski, D. J. (1971). Inappropriate secretion of antidiuretic hormone in reticulum cell sarcoma. Southern Medical Journal, 64, 763-764.

Russell, D. S., Marshall, A. H. E., and Smith, F. B. (1948). Microgliomatosis. A form of reticulosis affecting the brain. Brain, 71, 1-15.

Schaumburg, H. H., Plank, C. R., and Adams, R. D. (1972). The reticulum cell sarcoma-microglioma group of brain tumours. A consideration of their clinical features and therapy. Brain, 95, 199-212.

Schneck, S. A., and Penn, I. (1971). De-novo brain tumours in renal-transplant recipients. Lancet, 1, 983-986.

Sorger, K. (1963). Reticulum cell sarcoma of the central nervous system. Canadian Medical Association Journal, 89, 503-507.

Spriggs, A. I., and Boddington, M. M. (1959). Leukaemic cells in cerebrospinal fluid. British Journal of Haematology 5, 83-91.

Tomasi, T. B. Jr. (1968). Human immunoglobulin A. Ne England Journal of Medicine, 279, 1327-1330.

Williams, H. M., Diamond, H. D., Craver, L. F., an Parsons, H. (1959). Neurological Complications of Lymo phomas and Leukemias. Thomas: Springfield, III. 